\title{
The 3.5 Ga Siurua trondhjemite gneiss in the Archaean Pudas- järvi Granulite Belt, northern Finland
}

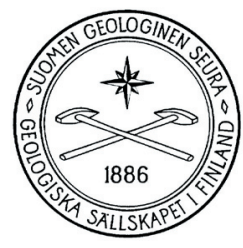

\author{
Tapani Mutanen ${ }^{1) *}$ and Hannu Huhma ${ }^{2}$ \\ ${ }^{1)}$ Geological Survey of Finland, P.O. Box 77, FIN-96101 Rovaniemi, Finland \\ ${ }^{2)}$ Geological Survey of Finland, P.O. Box 96, FIN-02151 Espoo, Finland
}

\begin{abstract}
In the Archaean Pudasjärvi Complex the pyroxene-bearing rocks are considered to form a belt, the Pudasjärvi Granulite Belt (PGB). The major rock types of the PGB are metaigneous mafic and felsic granulites, and trondhjemite gneisses. Red alaskites, white leucogranites and trondhjemitic pegmatoids are locally abundant. lon microprobe U-Pb analyses on zircons suggest a magmatic age of ca. $3.5 \mathrm{Ga}$ for the trondhjemite gneiss in Siurua, considered the oldest rock so far identified in the Fennoscandian Shield. The old age is supported by the Sm-Nd depleted mantle model age of $3.5 \mathrm{Ga}$, and by conventional U-Pb zircon data, which have provided a minimum age of $3.32 \mathrm{Ga}$. The U-Pb sims-data on the Siurua gneiss are, however, heterogeneous and suggest several stages of zircon growth, mostly at 3.5-3.4 Ga. An inherited core in one crystal provided an age of 3.73 $\mathrm{Ga}$, whereas the youngest two analyses yield ages of 3.1 and $3.3 \mathrm{Ga}$. Metamorphic monazite formed in the Siurua gneiss ca. $2.66 \mathrm{Ga}$ ago, roughly contemporaneously with the high-grade metamorphism recorded by zircon in a mafic granulite. Magmatic zircons from a felsic high-grade rock provide ages of ca. $2.96 \mathrm{Ga}$, but no zircons coeval with the 2.65 Ga metamorphism were detected by ion-microprobe. As a whole the PGB seems to be a tectonic block-mosaic containing rocks with $\mathrm{Sm}-\mathrm{Nd}$ crustal formation ages ranging from 3.5 to $2.8 \mathrm{Ga}$.
\end{abstract}

Key words: gneisses, granulites, diorites, alaskite, chemical composition, absolute age, U/Pb, zircon, Sm/Nd, Archean, Siurua, Pudasjärvi, Ranua, Finland

\section{Introduction}

The exposed Archaean crust in the Fennoscandian Shield consists of several natural or formal subdivisions, variously called "blocks", "areas", "complexes" or "belts". Here, the names proposed by Nironen et al. (2002) are used. The Pudasjärvi Complex is bounded to the north and south-southwest by Palaeoproterozoic schist belts and to the east by Palaeoproterozoic shear zones, rocks of the Central Lapland Granitoid Complex and the Archaean Eastern Finland Complex. Until recently the geology of the area has been relatively poorly known, partly due to limited outcrop.

During mineral exploration in 1998 in areas west and northwest of Pudasjärvi, granulite

\footnotetext{
* Corresponding author

e-mail: tapani.mutanen@gsf.fi
}

facies rocks were encountered in what proved to be an extensive belt. Four samples representing various rock types were chosen for isotopic dating, and the results of these studies are reported here. They reveal that a trondhjemite gneiss from Siurua, Pudasjärvi, seems to be the oldest primary crustal rock in the Fennoscandian Shield, with a minimum conventional U-Pb zircon age of $3.3 \mathrm{Ga}$. The age is noticeably older than the 3.1-3.2 Ga ages of the orthogneisses from Tojottamanselkä, Sodankylä (Kröner et al., 1981; Jahn et al., 1984; Kröner \& Compston, 1990), Lapinlahti (Paavola, 1986; Hölttä et al., 2000) and other parts of the Fennoscandian Shield (Shurkin et al., 1979; Mints et al., 1982; Hyppönen, 1983; Lobach-Zhuchenko et al., 1986; Sergeev et al., 1990; Chekulaev et al., 1997). 


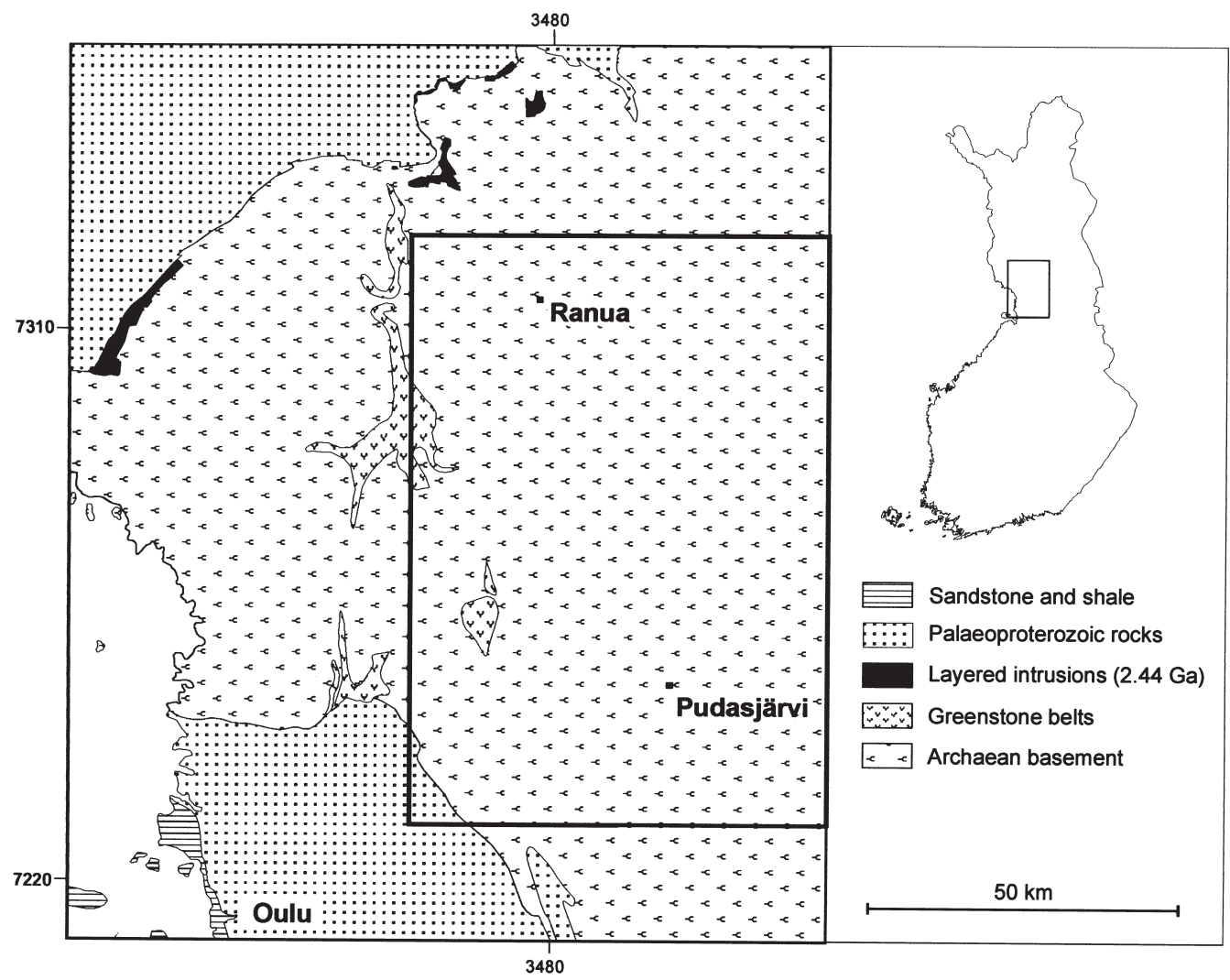

Fig. I. General geology of the Archaean Pudasjärvi Complex. The map is simplified after Korsman et al. (1997). Area of Fig. 3 outlined.

Rocks with Sm-Nd model ages $\left(\mathrm{T}_{\mathrm{DM}}\right)$ suggesting formation of sialic crust at 3.4-3.6 Ga are known from the Fennoscandian Shield (Jahn et al., 1984; Huhma et al., 1995; Hanski et al., 2001), and direct evidence of the ancient crust in that age range has been provided by the ion probe analyses from few detrital zircons (Claesson et al., 1993; Huhma et al., 2000). In Europe, zircons older than 3.5 Ga have been found in the Novopavlovsk Complex in the Ukrainian Shield (Bibikova \& Williams, 1990). The oldest reliably dated rocks on the Earth, e.g. the Itsaq Gneiss Complex, Greenland, give ages in the range 3.7-3.8 Ga (Nutman et al., 1996; Kamber et al., 2001). It has been questioned whether the $4 \mathrm{Ga}$ old zircons in the Acasta gneisses in Canada (Stern \& Bleeker, 1998; Bowring \& Williams, 1999) are cogenetic with their host rock or are inherited from an older source region (Kamber et al, 2001).

\section{General geology}

The north-south trending Pudasjärvi Granulite Belt (PGB) is located in the middle of the Archaean Pudasjärvi gneiss complex (Figs. 1 and 2), ca. $70 \mathrm{~km}$ northeast of Oulu. On the general geological map (1:400 000; Enkovaara et al., 1952 ; 1953) some of the rocks in the belt have been portrayed as mica schists containing either pyroxene or cordierite. The boundaries of the belt have not yet been delineated by systematic mapping. Based on the old map (Enkovaara et al., 1952) and new mapping data, the length of the PGB is at least $55 \mathrm{~km}$; the width seems to vary between 15 and $40 \mathrm{~km}$. The PGB is flanked 


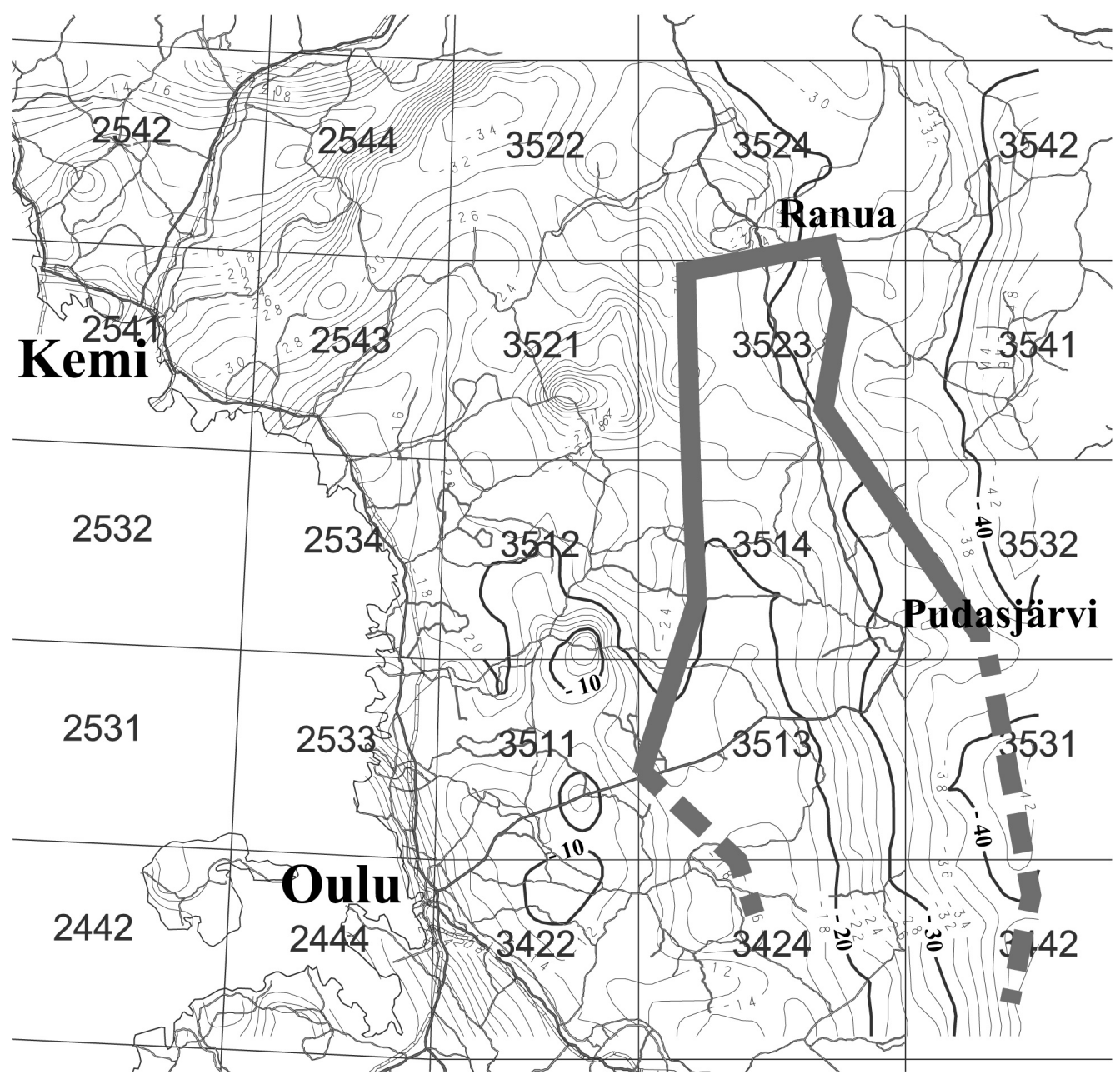

Fig. 2. Regional Bouguer gravity map of the Pudasjärvi Complex. The northern part of the block structure containing the Pudasjärvi Granulite Belt (PGB) is outlined. The PGB is located along the eastern slope of a marked (30 $\mathrm{mGal}$ ) regional positive Bouguer anomaly.

by wide areas of Archaean gneisses, still known in general features only. West of the PGB lies also the Oijärvi greenstone belt, with associated gold deposits (Tolppi, 1999). Reports of metamorphic pyroxene amongst Archaean gneisses east of the PGB (for example, Enkovaara et al., 1953, p. 26) suggest that outlier occurrences of granulites are more widespread in the eastern part of the Pudasjärvi Complex and the northern part of the Archaean Eastern Finland Complex. Archaean granulites are well exposed in the Iisalmi Complex, Central Finland (Paavola, 1986), where high-grade metamorphism at
9-11 kbar, and $800-900^{\circ} \mathrm{C}$ (Hölttä \& Paavola, 2000) has taken place at 2.6-2.7 Ga (Hölttä et al. 2000; Mänttäri \& Hölttä, 2002).

The Pudasjärvi Granulite Belt runs along the eastern flank of a regional positive gravity anomaly in the western part of the Pudasjärvi gneiss complex (Fig. 2). On the aeromagnetic map the PGB appears as a subdued feature, bounded and intersected by faults and ductile shears (Fig. 3). As a whole the PGB seems to be a tectonic block-mosaic. Two larger internal blocks with regular magnetic banding and fold structures can be discerned (Fig. 4), but otherwise patterns 


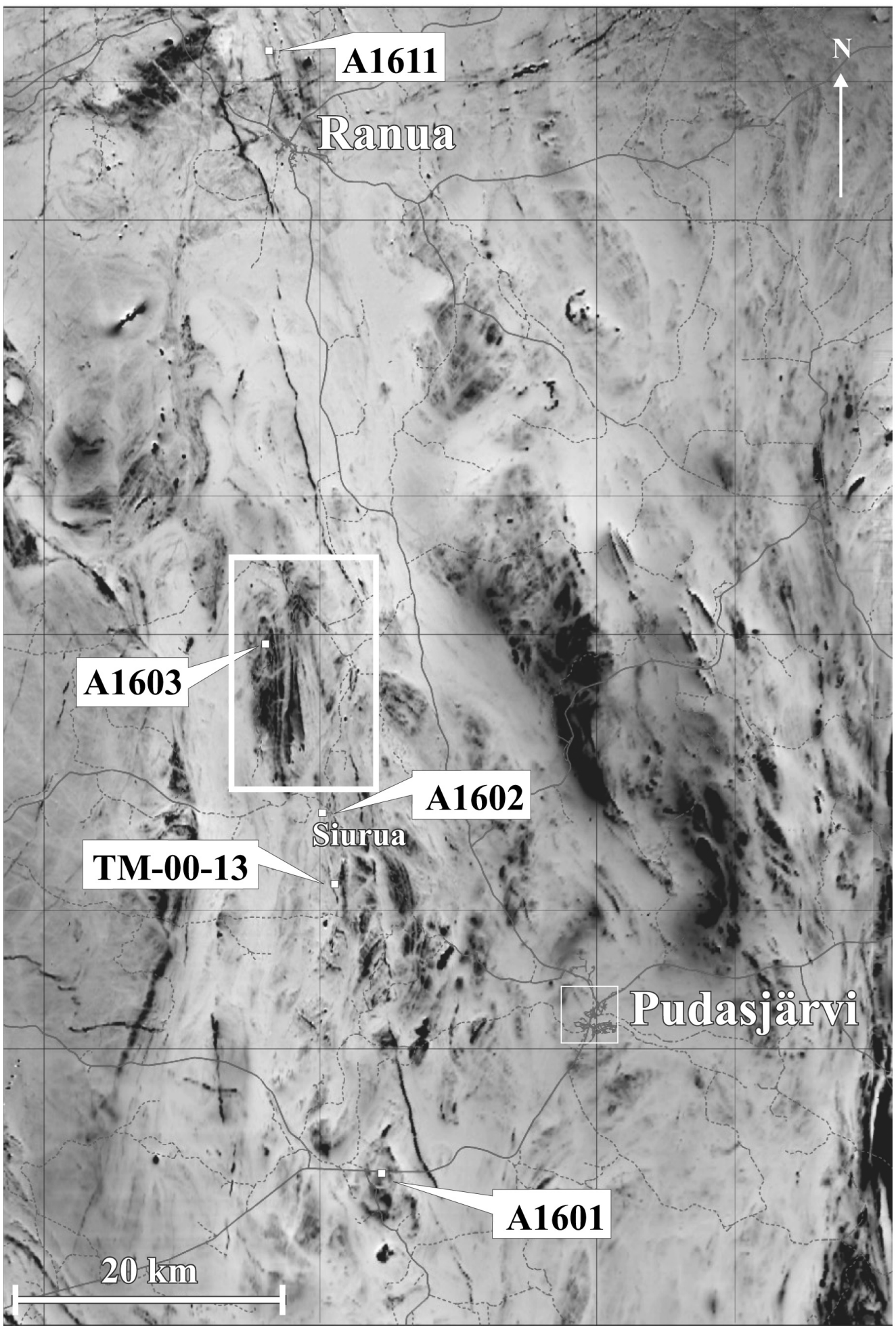

Fig. 3. Grey-tone low-altitude aeromagnetic map of the Pudasjärvi Granulite Belt and surroundings, with sample localities. Outlined area is shown enlarged in Fig. 4. 
of primary structures cannot be distinguished in the grey-tone low-altitude aeromagnetic maps. It appears, too, that inside the PGB slices of different metamorphic grades (amphibolite and granulite facies) and crustal ages are juxtaposed, which attests to considerable differential vertical movements. Inside the blocks, however, signs of penetrative deformation (such as foliation) seem to be generally lacking.

Under microscope the rocks have a polygonal mosaic granoblastic and, apparently, nonfoliate textures, with straight or slightly serrated grain boundaries. Triple boundary junctions at $120^{\circ}$ are common in mafic granulites. Preferred orientation, when found in microscope (Lalli, 2002) might indicate proximity of syntectonic, healed shear zones.

The PGB forms the southern part of a major long-lived, battered zone that registers intermittent post-PGB faulting and magmatic events. Southwards from the down-bulge at the northern contact of the Pudasjärvi gneiss complex with Palaeoproterozoic supracrustal rocks (Fig. 1), the zone includes blocks of $2.44 \mathrm{Ga}$ (Alapieti, 1982; Perttunen \& Vaasjoki, 2001) layered intrusions, diorites and other intrusive rocks in the Ranua area, magnetic mafic dykes of westerly, northerly and north-northwesterly trends. Non-magnetic gabbroic dykes, assumed feeders of the layered intrusions, occur near the northwestern (upper) border of the gneiss complex (Mutanen, 1989).

The most prominent faults run in northerly, northeasterly and north-northwesterly directions. The maximum (apparent) horizontal shift along a right-lateral fault is $8 \mathrm{~km}$. The youngest, anastomosing system of faults has a general trend between northwest and west-northwest.

\section{Petrography and geochemistry}

Most rocks of the Pudasjärvi Granulite Belt encountered in outcrops are presumed orthogneisses of mafic and felsic composition (trondhjemites, tonalites, alkali charnockites, alaskites). As a whole the assemblage of igneous rocks may represent bimodal (basaltic/felsic)

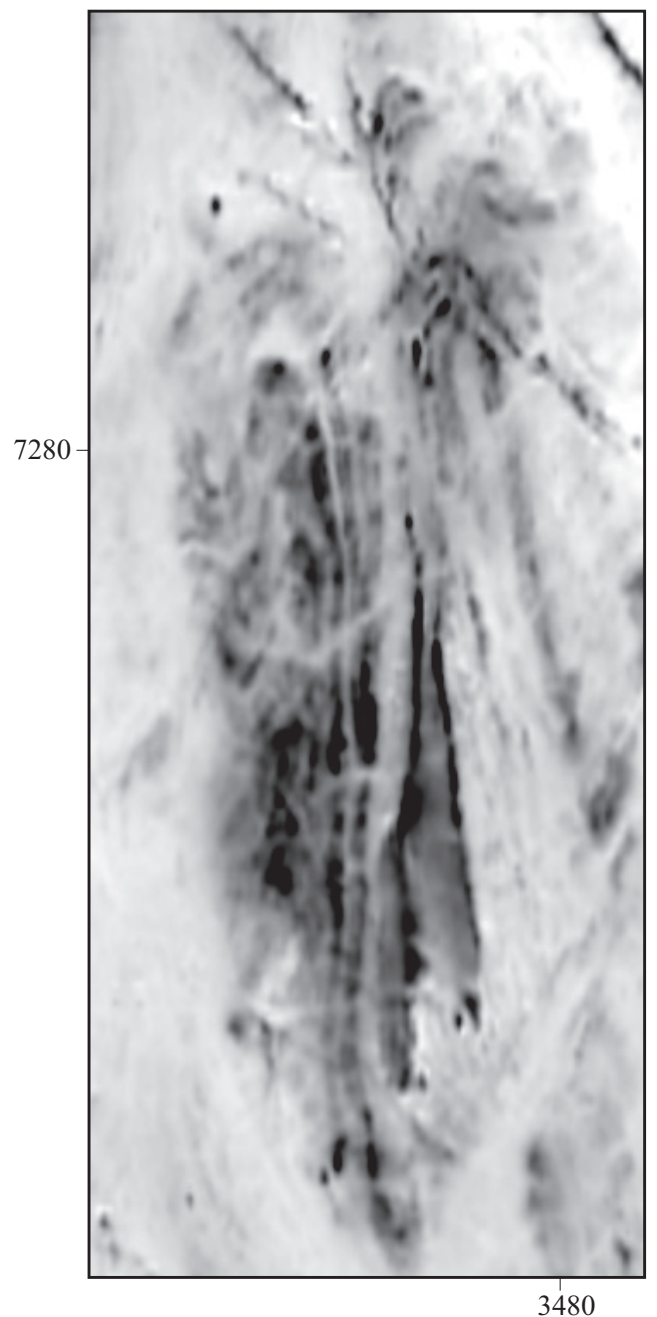

Fig. 4. Detail of aeromagnetic map of Fig. 3. The length of the magnetic structure from north to south is ca. $16 \mathrm{~km}$.

magmatism; the felsic members, however, could also be seen to represent new sialic crust characterized by an incomplete, or atypical TTG (tonalite-trondhjemite-granodiorite) association. The Ranua diorites, just north of the PGB, are massive igneous rocks. The major and trace element compositions of some type samples are given in Table 1 and the chondrite-normalized REE patterns in Fig. 5.

The mafic granulites, with pyroxenes and high-T metamorphic hornblende are called pyribolites (pyroxene amphibolites). These massive, granoblastic, medium-grained and non- 
Table I. Major and trace element analyses for rocks of the Pudasjärvi Granulite Belt and Ranua diorite.

\begin{tabular}{|c|c|c|c|c|c|}
\hline Sample & A1601 & A1602 & A 1603 & A1611 & TM-00-13 \\
\hline $\mathrm{SiO}_{2}$ & 49.4 & 70.3 & 73.3 & 56.0 & 75.3 \\
\hline $\mathrm{TiO}_{2}^{2}$ & 0.66 & 0.45 & 0.14 & 0.77 & 0.02 \\
\hline $\mathrm{Al}_{2} \mathrm{O}_{3}$ & 15.1 & 15.6 & 14.8 & 18.1 & 13.3 \\
\hline $\mathrm{Fe}_{2}^{2} \mathrm{O}_{3}^{3}(\mathrm{t})$ & 10.9 & 2.33 & 1.28 & 7.73 & 0.91 \\
\hline $\mathrm{MnO}$ & 0.19 & 0.02 & 0.02 & 0.13 & 0.04 \\
\hline $\mathrm{MgO}$ & 7.89 & 0.92 & 0.44 & 2.98 & $<0.03$ \\
\hline $\mathrm{CaO}$ & 11.7 & 3.17 & 2.61 & 6.92 & 0.58 \\
\hline $\mathrm{Na}_{2} \mathrm{O}$ & 2.34 & 4.48 & 4.17 & 4.73 & 3.81 \\
\hline $\mathrm{K}_{2} \mathrm{O}$ & 0.19 & 1.83 & 2.79 & 0.90 & 5.32 \\
\hline $\mathrm{P}_{2} \mathrm{O}_{5}$ & 0.04 & 0.03 & 0.04 & 0.34 & $<0.01$ \\
\hline Sum & 98.41 & 99.13 & 99.59 & 98.60 & 99.30 \\
\hline $\mathrm{Cr}$ & 306 & $<30$ & $<30$ & 30 & $<30$ \\
\hline $\mathrm{Ni}$ & 121 & 8 & 5 & 6 & $<4$ \\
\hline Co & 42 & 5.6 & 2.4 & 15 & $<0.5$ \\
\hline V & 241 & 32 & 14 & 126 & $<0.5$ \\
\hline Sc & 46 & 3.6 & 1.8 & 16 & 2.5 \\
\hline $\mathrm{Sr}$ & 127 & 311 & 449 & 1047 & 18 \\
\hline $\mathrm{Ba}$ & 33 & 503 & 970 & 665 & 170 \\
\hline $\mathrm{Rb}$ & 0.4 & 57 & 59 & 14 & 91 \\
\hline $\mathrm{Zr}$ & 32 & 294 & 66 & 142 & 55 \\
\hline $\mathrm{Hf}$ & 1.0 & 6.9 & 1.7 & 3.2 & 2.8 \\
\hline $\mathrm{Ta}$ & 0.2 & $<0.2$ & $<0.2$ & $<0.2$ & 1.8 \\
\hline $\mathrm{Nb}$ & 1.8 & 5.2 & 0.7 & 4.3 & 2.3 \\
\hline $\mathrm{Pb}$ & $<30$ & 32 & $<30$ & $<30$ & 34 \\
\hline U & $<0.2$ & 2.0 & $<0.2$ & $<0.2$ & 0.5 \\
\hline Th & $<0.5$ & 46 & $<0.5$ & 0.6 & 4.7 \\
\hline Y & 19 & 7.5 & 1.5 & 20 & 21 \\
\hline $\mathrm{La}$ & 4.03 & 123 & 11.4 & 27.3 & 8.59 \\
\hline $\mathrm{Ce}$ & 10.6 & 213 & 17.2 & 62.8 & 16.2 \\
\hline $\operatorname{Pr}$ & 1.72 & 22.2 & 1.70 & 8.58 & 1.65 \\
\hline $\mathrm{Nd}$ & 8.08 & 75.8 & 5.83 & 36.2 & 5.61 \\
\hline $\mathrm{Sm}$ & 2.17 & 10.0 & 0.69 & 6.65 & 1.01 \\
\hline $\mathrm{Eu}$ & 0.83 & 1.35 & 0.35 & 1.75 & 0.12 \\
\hline $\mathrm{Gd}$ & 2.70 & 6.77 & 0.66 & 5.98 & 1.24 \\
\hline $\mathrm{Tb}$ & 0.49 & 0.59 & $<0.1$ & 0.72 & 0.29 \\
\hline Dy & 3.20 & 1.90 & 0.29 & 3.76 & 2.65 \\
\hline Ho & 0.70 & 0.27 & $<0.1$ & 0.67 & 0.72 \\
\hline $\mathrm{Er}$ & 2.01 & 0.60 & $<0.15$ & 1.87 & 2.31 \\
\hline $\mathrm{Tm}$ & 0.27 & $<0.1$ & $<0.1$ & 0.26 & 0.38 \\
\hline $\mathrm{Yb}$ & 0.96 & 0.55 & $<0.15$ & 1.63 & 2.64 \\
\hline $\mathrm{Lu}$ & 0.26 & $<0.1$ & $<0.1$ & 0.23 & 0.38 \\
\hline S & 340 & $<100$ & $<100$ & $<100$ & $<100$ \\
\hline $\mathrm{Cl}$ & $<60$ & 170 & $<60$ & 210 & $<60$ \\
\hline $\mathrm{Cu}$ & 49 & $<5$ & 14 & 11 & $<5$ \\
\hline $\mathrm{Ga}$ & 14 & 22 & 15 & 23 & 16 \\
\hline $\mathrm{Zn}$ & 85 & 52 & 22 & 105 & $<10$ \\
\hline $\mathrm{F}$ & 600 & 600 & 300 & 600 & $<100$ \\
\hline
\end{tabular}

Major oxides (wt. \%) and S, Cl, Cr, Sr, Ba, and Pb (ppm) by XRF; REE and other trace elements (ppm) by ICP-MS; $\mathrm{F}$ (ppm) by potentiometric $\mathrm{NaOH}$-fusion; all analyses are made at the laboratory of the Geological Survey of Finland, Espoo. Total iron as $\mathrm{Fe}_{2} \mathrm{O}_{3}(\mathrm{t})$.

foliate rocks consist of plagioclase $\left(\mathrm{An}_{36-72}\right.$, Lalli, 2002), clinopyroxene, orthopyroxene and brown or greenish brown hornblende; sparse biotite is sometimes present. Accessory minerals are fluorapatite, magnetite, ilmenite, pyrrho- tite (with exsolved flake pentlandite) and chalcopyrite. Exsolved lamellar ilmenite in magnetite is common. Secondary minerals are pyrite and carbonate. Rare zircon occurs as euhedral stubby crystals. 
Retrograde alteration, where present, has produced dark green hornblende and minor colourless amphibole (cummingtonite?) from pyroxene. The alteration advanced from grain boundaries and sometimes consumed the original pyroxene entirely, but even then brown hornblende usually has remained intact. Other retrograde minerals are titanite (from ilmenite), epidote, biotite and pyrite.

These mafic granulites are interpreted to be basaltic rocks (see Table 1, A1601) with a fairly flat REE pattern (Fig. 5), probably metalavas not materially affected by crystal fractionation or crustal contamination.

The Siurua trondhjemite gneiss is the dominant rock in a large outcrop area. It is the only rock type among the samples of PGB which is not, at least in its present state, of granulite facies. Salic segregations in trondhjemite in the Siurua outcrop and, locally, in mafic granulites, as well as narrow (usually $<20 \mathrm{~cm}$ ), gneissosity-parallel veins of granite pegmatites in Siurua trondhjemite suggest anatexis. The rock is granoblastic, medium-grained and consists of plagioclase $\left(\mathrm{An}_{27}\right)$, quartz, potassium feldspar (slightly perthitic microcline), dark biotite and accessory fluorapatite, zircon, monazite (inclusions in biotite), ilmenite, magnetite and metamict allanite. According to electron microprobe analyses the monazite contains $0.26-0.66$ wt $\%$ $\mathrm{U}$ and $0.80-1.01 \mathrm{wt} \% \mathrm{~Pb}$. In some samples zircon has peculiar goethite mantles. Dark green hornblende and garnet occur in one sample. Alteration products are carbonate, chlorite (from biotite), epidote and muscovite (from plagioclase), titanite and rutile (from ilmenite) and hematite ("martite", from magnetite). Textural relations suggest that part of the biotite was formed from garnet. Some of the microcline may also arise from material emanated from granite pegmatite veins. Gneissic banding is seen on outcrop but penetrative deformation is not noticeable under the microscope.

The chemical composition of the Siurua trondhjemite gneiss (Table 1, A1602) is close to the average Archaean TTG gneisses (Martin, 1994). The major differences are the de-
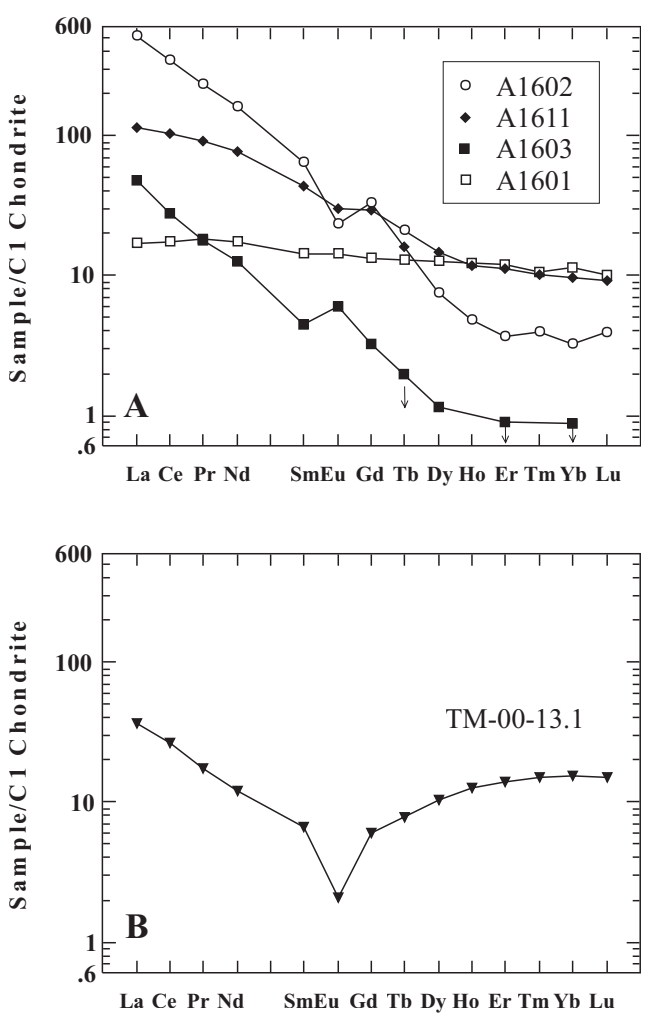

Fig. 5. REE (chondrite normalized) patterns of, a) Siurua gneiss (AI602), Ranua diorite (AI6II), and felsic (AI603) and mafic (AI60I) granulite samples, b) "timberman alaskite". $\mathrm{Cl}$ chondrite values from Sun and McDonough (1989).

pletion of phosphorus and strong enrichment of Th and LREE.

The felsic granulites are medium-grained, granoblastic and apparently unfoliated rocks consisting mainly of plagioclase $\left(\mathrm{An}_{27-35}\right)$, quartz, orthopyroxene and clinopyroxene. Potassium feldspar occurs in interstices and as antiperthite in plagioclase. Biotite is a regular minor constituent in the most felsic types, but in more mafic variants brown hornblende takes its stead. Accessory phases identifiable under microscope are fluorapatite, zircon (sometimes with discordant growth zones), magnetite and ilmenite (sometimes ilmenite alone). As in mafic granulites there is also lamellar exsolved ilmenite in magnetite. Chalcopyrite, bornite and chalcocite are occasionally encountered. Pyrrhotite occurs in very small amounts either as 
small free grains or as tiny inclusions in magnetite. Rare pyrite may be a secondary phase. Typical retrograde minerals are titanite, hematite ("martite"), carbonate, clinozoisite-epidote, chlorite, marcasite and goethite. The complete lack of exsolved hematite in ilmenite attests to reducing crystallization (equilibration) conditions (e.g., Frost 1991), while absence of martitization of magnetite implies that no retrograde (and supergene) oxidation took place. The rocks are completely recrystallized in prograde metamorphism to the extent that no tokens of primary igneous textures are left.

On account of their modal and major element compositions (Table 1, A1603) the felsic granulites (alkali charnockites) pass as trondhjemites (O'Connor, 1965). Typically they are leucocratic; in the type sample A1603 the sum of normative quartz and feldspar is $95 \%$. However, larger sample set suggests spreading over to the tonalite field (Lalli, 2002). The REE patterns of the felsic granulites and the Siurua trondhjemite have a similar, LREE-enriched shape; however, the REE concentrations of the Siurua trondhjemite are about an order of magnitude higher (Fig. 5). Both show a negative Eu (CN) anomaly. Distinct from these is the flatter LREE pattern of the intrusive diorites of the Ranua area, just north of the PGB.

Alaskites are formally high-silica hypersolvus granites. These medium-grained, granular (granoblastic), texturally massive rocks are composed of perthitic microcline, quartz and very small amounts of independent plagioclase. Spessartite-rich garnet is a scarce but regular constituent and has partly reacted to biotite. Secondary and accessory minerals are muscovite, chlorite, magnetite, hematite (martite after magnetite), rutile, zircon and a few tiny grains of cassiterite and gold (these latter found only by EMP scanning). The proportion of perthite in microcline is so high as to contain almost all of the plagioclase in the rock. The marginal parts of microcline contain a smaller proportion of perthite. The interiors of the independent plagioclase grains are characteristically smudged by iron hydroxides.
Compared to average crustal composition the alaskites are strongly depleted of $\mathrm{Mg}, \mathrm{Ca}$, $\mathrm{Fe}, \mathrm{P}, \mathrm{Ti}$ and $\mathrm{Sr}$ (Table 1, TM-00-13). Their REE pattern (Fig. 5b) is peculiar, having the general form of timberman's (Acanthocinus aedilis) tentacles (hence the appellation "timberman alaskite"), so that from LREE and HREE ends the curve drops toward Eu. The REE pattern of another granite from the Isokumpu area is similar but HREE are still more enriched (Lalli, 2002, App. 1). The alaskites are also high in Y (20-60 ppm). The modal and major element composition of the timberman alaskite magma represents a dry granite minimum $\left(>900^{\circ} \mathrm{C}\right.$, e.g., Sood 1981; Carmichael et al. 1974), or metamorphic recrystallization within the same temperature range. The strong to extreme depletion of the elements listed above indicates that the alaskite magma resulted from considerable crystal fractionation.

The leucogranites are geochemically related to alaskites. They are white subsolvus granites with independent oligoclasic plagioclase. The microcline contains little or no perthite. The amounts on dark minerals (biotite, garnet) and muscovite are small. Zircon occurs as euhedral short prismatic crystals. Other accessory minerals encountered are fluorapatite, ilmenite, magnetite, monazite, pyrrhotite, pyrite, chalcopyrite, mackinawite and molybdenite. Secondary minerals are green hydrobiotite (from garnet), chlorite (from biotite), rutile (from ilmenite), hematite ("martite", from magnetite), marcasite (from pyrrhotite) and carbonate.

With the decrease of microcline the leucogranites grade to granodiorites and trondhjemites.

Trondhjemite pegmatoids form narrow (usually less than one metre) bands in the proximity of other granitic rocks. These coarse-grained reddish rocks consist of plagioclase, variable amounts of quartz and biotite. The amount of microcline (often as antiperthite in plagioclase) is typically small. In places quartz is practically lacking. Zircon and monazite occur as large crystals, often visible with the naked eye. Other accessory and secondary minerals are magnetite, 
ilmenite (partly altered to titanite and rutile), chalcopyrite, pyrite, pyrrhotite (as inclusions in pyrite), galena (?), chlorite, carbonate, muscovite and epidote. These rocks are very rich in $\mathrm{Th}$ (up to $481 \mathrm{ppm}$ ), LREE (Ce and La up to 4720 ppm and 2500 ppm, respectively).

The Ranua diorites, just north of the Pudasjärvi Granulite Belt, are massive igneous rocks. Diorite occurs in a relatively large area characterized by a positive regional gravity anomaly, and forms large outcrops in the northern part of the supposed intrusion area. These medium-grained rocks consist of plagioclase, green or bluish green hornblende and dark brown biotite, and always contain a fair amount of quartz in interstices. The original lath-shaped plagioclase is altered to coarse epidote and to albite-oligoclase. Accessories and alteration products are magnetite (partially or wholly oxidized to hematite), ilmenite (with exsolved hematite), fluorapatite, titanite, rutile, pyrite and zircon. Vestiges of igneous origin are seen in the shape of plagioclase grains and rare trellis texture of ilmenomagnetite, but otherwise the granoblastic textures and paragenesis represent later metamorphic overprint(s) and retrograde reactions. Apart from local sheared variants the rocks are massive.

The granulite mineral assemblages of the $\mathrm{Pu}$ dasjärvi Granulite Belt represent water-deficient low-P high-T metamorphic conditions. For felsic granulites, however, the P-T conditions estimated from mineral reactions are surprisingly mild (2.5-3.5 kbar, $\left.500-600^{\circ} \mathrm{C}\right)$; only one sample gave $5.5 \mathrm{kbar}$ and $650^{\circ} \mathrm{C}$ (Lalli, 2002). For mafic granulites the metamorphic temperatures are $700-800{ }^{\circ} \mathrm{C}$ and maximum possible pressures ca 6.5-7 kbar (op.cit.). According to Lalli (2002) after the metamorphic peak conditions the rocks underwent a rapid, practically isothermal decompression, and the minerals equilibrated at tempered conditions. In the PGB a ubiquitous cooling "speedometer" is available: lamellar ilmenite exsolution bodies in magnetite (in contrast to granule exsolution) indicate rapid cooling through the Fe-Ti oxide solvus (at or below $600^{\circ} \mathrm{C}$, e.g., Price 1981; Lindsley, 1991). This, along with relatively feeble manifestations of retrograde processes, suggests exceedingly rapid ascent and exhumation of the PGB fault block terrain.

\section{Methods for isotopic analyses}

Zircons from four rock samples were separated and analysed following methods by Krogh (1973). Procedures for conventional analyses involved aliquoting the $\mathrm{HCl}$ solution and addition of ${ }^{208} \mathrm{~Pb} /{ }^{235} \mathrm{U}$ isotopic tracer ${ }^{206} \mathrm{~Pb} /{ }^{235} \mathrm{U}$ tracer for monazite). Measurements were made using a VG Sector 54 mass spectrometer. The performance of the ion counter was checked by repeated measurements of a NBS 983 standard.

$\mathrm{U}-\mathrm{Th}-\mathrm{Pb}$ spot analyses of zircons were performed using Cameca IMS1270 ion-microprobe at the Swedish Museum of Natural History, Stockholm (NORDSIM facility). The analytical procedure is described in Whitehouse et al. $(1997,1999)$. The spot-diameter for the $4 \mathrm{nA}$ primary $\mathrm{O}_{2}^{-}$ion was ca. $30 \mu \mathrm{m}$, and oxygen flooding was used to improve the ionization of $\mathrm{Pb}$. Calibration of the $\mathrm{U} / \mathrm{Pb}$ ratio was based on analyses of the Geostandards zircon 91500, which has an age of $1065 \mathrm{Ma}$ (Wiedenbeck et al., 1995). Corrections for common $\mathrm{Pb}$ are based upon the measured ${ }^{204} \mathrm{~Pb}$ signal and the present day terrestrial average $\mathrm{Pb}$-isotopic composition is used for this correction (Stacey $\&$ Kramers, 1975). Data reduction was performed using Nordsim software written by M.J. Whitehouse, and age calculations were made using Isoplot/Ex 2.49 (Ludwig, 2001). Using BSEimages 30 zircon analysis points were selected and measured from two rock samples.

For Sm-Nd analyses the sample dissolution was performed in sealed teflon bombs, and a mixed ${ }^{150} \mathrm{Nd}-{ }^{149} \mathrm{Sm}$ spike solution was added to the sample prior the dissolution. Chemical separation of $\mathrm{Sm}$ and $\mathrm{Nd}$ followed methods by Richard et al. (1976). Measurements were made on a VG Sector 54 mass spectrometer using Ta-Re triple filaments and a dynamic mode of measurements. Nd ratios are normalized to ${ }^{146} \mathrm{Nd} /{ }^{144} \mathrm{Nd}=0.7219$. Measurements of 
the ${ }^{143} \mathrm{Nd} /{ }^{144} \mathrm{Nd}$ in the La Jolla standard during 1995-2000 have yielded a ratio of $0.511850 \pm$ 0.000007 (standard deviation, $\mathrm{n}=60$ ). The $\mathrm{Sm} /$ $\mathrm{Nd}$ ratio of the spike was calibrated against the Caltech mixed $\mathrm{Sm} / \mathrm{Nd}$ standard (Wasserburg et $\mathrm{al}$ 1981). Based on duplicated analyses the error in ${ }^{147} \mathrm{Sm} /{ }^{144} \mathrm{Nd}$ is estimated to be $0.4 \%$. Initial ${ }^{143} \mathrm{Nd} /{ }^{144} \mathrm{Nd}$ and $\varepsilon$ were calculated with the following parameters: $\lambda^{147} \mathrm{Sm}=6.54 \times 10^{-12} \mathrm{a}^{-1},{ }^{147} \mathrm{Sm} /$ ${ }^{144} \mathrm{Nd}=0.1966$ and ${ }^{143} \mathrm{Nd} /{ }^{144} \mathrm{Nd}=0.51264$ for present CHUR. $\mathrm{T}_{\mathrm{DM}}$ was calculated according to DePaolo (1981). Programs by Ludwig (1991, 2001) have been used for age calculations.

\section{Results and Discussion}

\section{I. Zircon ages}

Sample A1601, Rankkila, Pudasjärvi, mafic granulite, map sheet 351309 , Finnish national grid coordinates $\mathrm{x}=7241.20$ (northing), $\mathrm{y}=3485.00$ (easting).

The outcrop by the Oulu-Pudasjärvi road consists of grey-black granoblastic pyroxene amphibolite (pyribolite), with only slight retrogressive alteration of pyroxenes to secondary amphiboles. The sample yielded a small amount of zircon, which consists mainly of very transparent, colourless, equant, and subhedral grains without distinct internal structure. Many grains have a rounded shape, and the appearance of zircon is likely metamorphic.

The regression of the four discordant $\mathrm{U}-\mathrm{Pb}$ analyses (Table 2 ) provides intercepts with the concordia curve at $2650 \pm 20 \mathrm{Ma}$ and $156 \pm 250$ Ma (MSWD=5.7, Fig. 6). The data reveal that the $\mathrm{U}$ concentration in the zircon is very low (10 ppm), and thus accidental procedural blank may have some influence on the analyses. Rejecting the relatively poor analysis $\mathrm{B}$, the other data are perfectly on a chord, which gives intercepts at $2652 \pm 4 \mathrm{Ma}$ and $157 \pm 48 \mathrm{Ma}(\mathrm{MSWD}=0.6)$. In any case, the ${ }^{207} \mathrm{~Pb} /{ }^{206} \mathrm{~Pb}$ age of $2648 \pm 3 \mathrm{Ma}$ for the least discordant analysis (D) with a relatively high ${ }^{206} \mathrm{~Pb} /{ }^{204} \mathrm{~Pb}$-ratio should be considered the minimum age for zircon. It remains somewhat obscure why the analyses on such low-uranium zircon are discordant. In spite of some scatter in the analytical results it is suggested that small amounts of metamorphic zircon had formed ca. 2.65 Ga ago in this mafic rock. This age is within the range obtained for the metamorphic monazite and zircon in the Varpaisjärvi granulites in eastern Finland (Huhma et al., 1995; Hölttä et al., 2000; Mänttäri \& Hölttä, 2002).

Sample A1602 Siurua, Pudasjärvi, trondhjemite gneiss, map sheet 3514 08, coordinates $\mathrm{x}=7267.09, \mathrm{y}=3480.52$.

The sample was collected from a relatively large outcrop area consisting mainly of slightly banded trondhjemites, with lesser amounts of darker granitoids containing garnet and hornblende. In the southern part of the outcrop area boudins of dark green mafic rocks, from $10 \mathrm{~cm}$ to $>2 \mathrm{~m}$ wide, appear to be metamorphosed dykes. Zircons separated from the sample are generally small euhedral prisms, short to moderately elongate and rounded on edges due to resorption. The colour ranges from pale brown to colourless, the grains are generally translucent. In the HF-etched section oscillatory zoning is very distinct. The sample also yielded yellow grains of monazite in the magnetic fraction.

The monazite analysis shows very high $U$ and $\mathrm{Pb}$ and provides a concordant age of $2660 \pm 2 \mathrm{Ma}$ (Table 2 and Fig. 6). This is similar to the age of the metamorphic zircon in the mafic granulite (A1601) discussed above.

The five conventional U-Pb analyses on zircon are discordant and do not give any decent chord on the concordia diagram (Fig. 6). Particularly the analysis A1602B is off and has a radiogenic ${ }^{208} \mathrm{~Pb} /{ }^{206} \mathrm{~Pb}$ markedly higher than the other analyses (Table 2). This is likely due to a minor amount of monazite in the aberrant analysis. As the $\mathrm{Pb}$ concentration in monazite is very high, only $0.0005 \mathrm{mg}$ (less than one grain) would be needed to change the $\mathrm{Pb} / \mathrm{Pb}$ ratios. However, even rejecting this analysis the four points do not plot exactly on a line as the calculation gives intercepts at $3361 \pm 78 \mathrm{Ma}$ and $1223 \pm 840 \mathrm{Ma}$, and a large MSWD=16. Nevertheless, it is obvious that the ${ }^{207} \mathrm{~Pb} /{ }^{206} \mathrm{~Pb}$ ages of 


\begin{tabular}{|c|c|c|c|c|c|c|c|c|c|c|c|c|c|c|c|c|c|c|c|c|c|c|c|}
\hline \multirow{3}{*}{ 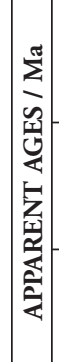 } & 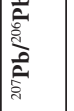 & & 帘 & $\begin{array}{l}\text { त्र } \\
\text { ते }\end{array}$ & $\begin{array}{l}\stackrel{\mathbb{J}}{N} \\
\text {. }\end{array}$ & 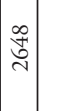 & & ๙ેे & $\begin{array}{l}\stackrel{2}{\text { }} \\
\text { }\end{array}$ & : & 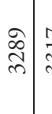 & $\overrightarrow{\tilde{m}}$ & 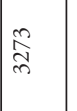 & & તิ & $\frac{m}{\stackrel{i}{2}}$ & $\begin{array}{l}\overrightarrow{\widetilde{D}} \\
\stackrel{\sim}{\sim}\end{array}$ & ๙ે & & ब్ & 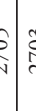 & 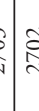 & \\
\hline & 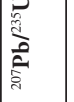 & & 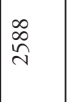 & $\stackrel{\text { sf }}{\stackrel{d}{d}}$ & $\begin{array}{l}\infty \\
\stackrel{\text { సे }}{ }\end{array}$ & $\begin{array}{l}m \\
\vdots \\
\end{array}$ & & $\stackrel{\vec{\sim}}{\vec{m}}$ & 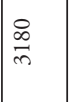 & : & $\begin{array}{ll}n \\
m \\
z\end{array}$ & 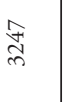 & $\frac{\hat{n}}{m}$ & & $\begin{array}{l}\text { Wे } \\
\text { }\end{array}$ & 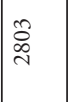 & 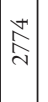 & 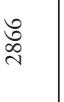 & & ¿ొ & 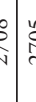 & & \\
\hline & 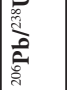 & & $\overrightarrow{\widetilde{\curvearrowright}}$ & 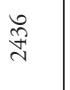 & 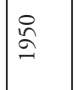 & 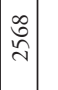 & & 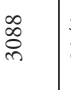 & 总 & స్త్ర & $\hat{\grave{\hat{े}}}$ & $\frac{\vec{m}}{m}$ & $\begin{array}{l}\stackrel{0}{\text { iे }} \\
\text { an }\end{array}$ & & ત્ર & 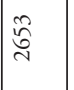 & $\begin{array}{l}\stackrel{0}{0} \\
\text { in }\end{array}$ & $\begin{array}{l}\text { ডે } \\
\text { ते }\end{array}$ & & & $E$ & & \\
\hline \multicolumn{2}{|c|}{ 营 } & & gे & ठे & $\stackrel{\infty}{\stackrel{0}{0}}$ & $\hat{\delta}$ & & 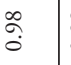 & $\stackrel{\infty}{2}$ & $\hat{\hat{o}}$ & $\begin{array}{l}\infty \\
\stackrel{b}{\delta}\end{array}$ & $\stackrel{\infty}{\circ}$ & $\stackrel{\infty}{\stackrel{\infty}{0}}$ & & 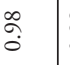 & $\stackrel{\infty}{\stackrel{\infty}{0}}$ & 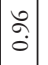 & $\stackrel{\infty}{\stackrel{0}{\delta}}$ & & $\tilde{\delta}$ & 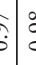 & 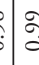 & \\
\hline \multirow{6}{*}{ 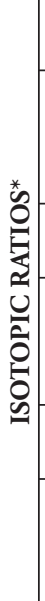 } & $\begin{array}{l}\text { Oे } \\
\text { N }\end{array}$ & & $\stackrel{n}{8}$ & $\approx$ & $\stackrel{\leftrightarrow}{0}$ & בֶ. & & $\overrightarrow{0}$ & $\overrightarrow{0}$ & $\stackrel{\text { I }}{\circ}$ & $=$ & $\overrightarrow{0}$ & $\overrightarrow{0}$ & & $\overrightarrow{0}$ & $\overrightarrow{0}$ & $\stackrel{\sim}{\stackrel{0}{0}}$ & $\overrightarrow{0}$ & & ? & ?̦. & 0 & \\
\hline & 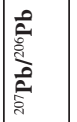 & & $\begin{array}{l}\stackrel{8}{\circ} \\
\stackrel{1}{1} \\
\stackrel{0}{0}\end{array}$ & 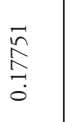 & $\begin{array}{l}\stackrel{2}{0} \\
\stackrel{0}{0}\end{array}$ & 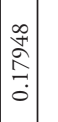 & & 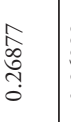 & 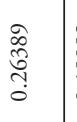 & $\begin{array}{l}\stackrel{0}{\infty} \\
\infty \\
\stackrel{\infty}{0} \\
\stackrel{0}{0}\end{array}$ & 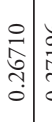 & 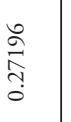 & 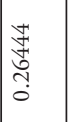 & & 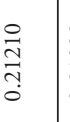 & $\begin{array}{l}\text { ô } \\
\text { ปั } \\
\text { ô }\end{array}$ & 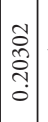 & 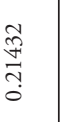 & & 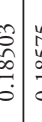 & 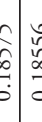 & 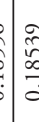 & \\
\hline & \begin{tabular}{|l} 
iे \\
ì \\
\end{tabular} & & 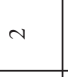 & m & u & N & & $\tilde{o}$ & $\approx$ & $\because$ & $\because$ & $\because$ & $\because$ & & $\approx$ & $\tilde{o}$ & $\because$ & $\tilde{o}$ & & $\stackrel{f}{b}$ & - & 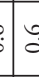 & \\
\hline & 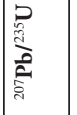 & & 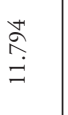 & 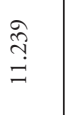 & $\begin{array}{l}\cong \\
\stackrel{\infty}{\infty} \\
\infty\end{array}$ & $\begin{array}{l}\stackrel{ \pm}{\Xi} \\
\stackrel{\vec{I}}{二}\end{array}$ & & & 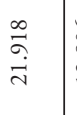 & 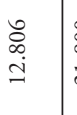 & 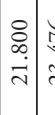 & 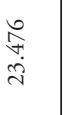 & 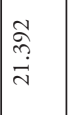 & & 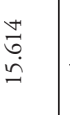 & $\begin{array}{l}\stackrel{0}{0} \\
\infty \\
\stackrel{+}{-}\end{array}$ & 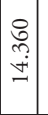 & $\begin{array}{l}\infty \\
\stackrel{\infty}{\infty} \\
\\
\end{array}$ & & $\begin{array}{l}\overrightarrow{\widehat{a}} \\
\stackrel{\vec{g}}{a}\end{array}$ & 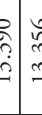 & & \\
\hline & $\begin{array}{l}\text { Oे } \\
\text { ஸे }\end{array}$ & & $\sim$ & m & u & 4 & & $\tilde{o}$ & $\approx$ & $\because$ & $\because$ & $\stackrel{n}{\circ}$ & $\because$ & & $\because$ & $\because$ & $\because$ & $\because$ & & $\hat{o}$ & - & & \\
\hline & 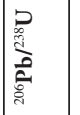 & & 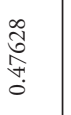 & 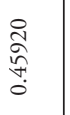 & $\begin{array}{l}\stackrel{n}{\vec{n}} \\
\hat{n} \\
0\end{array}$ & 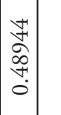 & & 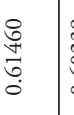 & 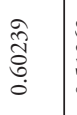 & $\begin{array}{l}\hat{\delta} \\
\hat{n} \\
\hat{n} \\
\hat{o}\end{array}$ & 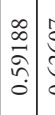 & 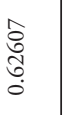 & \begin{tabular}{l}
$R$ \\
$\hat{D}$ \\
$\infty$ \\
\hdashline \\
0
\end{tabular} & & 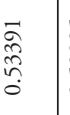 & $\begin{array}{l}\text { ते } \\
\hat{\sigma} \\
\hat{0} \\
\hat{o}\end{array}$ & $\left|\begin{array}{l}\overrightarrow{0} \\
\tilde{n} \\
0 \\
0\end{array}\right|$ & $\begin{array}{l}\text { ते } \\
\hat{\tilde{n}} \\
\hat{\sigma}\end{array}$ & & 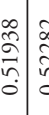 & 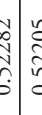 & & \\
\hline \multicolumn{2}{|c|}{ 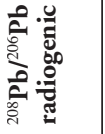 } & & 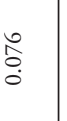 & $\begin{array}{l}\infty \\
: \\
0\end{array}$ & $\begin{array}{l}\infty \\
0 \\
0 \\
0\end{array}$ & $\mid$\begin{tabular}{|c}
$\hat{a}$ \\
0 \\
0
\end{tabular} & & 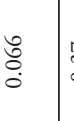 & $\hat{\tilde{o}}$ & $\vec{r}$ & $\mid$ & 苂 & $\vec{\Xi}$ & & $\overrightarrow{0}$ & $\overrightarrow{0}$ & $\begin{array}{l}\infty \\
0 \\
0 \\
0\end{array}$ & $\begin{array}{l}\stackrel{\infty}{\infty} \\
\stackrel{0}{\circ}\end{array}$ & & त्ञ & ț: & & \\
\hline \multicolumn{2}{|c|}{ 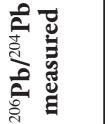 } & & 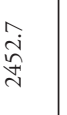 & $\begin{array}{l}\overrightarrow{0} \\
\stackrel{0}{0} \\
0\end{array}$ & & 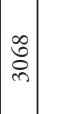 & & $\frac{n}{m}$ & 芯 & 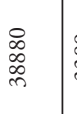 & $\begin{array}{c}\hat{\alpha} \\
\hat{m} \\
\cdots\end{array}$ & 卞 & ๙ૂે & & 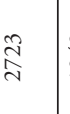 & 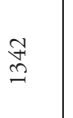 & $\begin{array}{l}n \\
\tilde{\vec{n}} \\
\end{array}$ & $\stackrel{n}{ٍ}$ & & مे. & : & 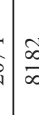 & \\
\hline $\overrightarrow{2}$ & 竞 & & $\overrightarrow{\tilde{n}}$ & $\begin{array}{l}\stackrel{i}{ } \\
\text { in }\end{array}$ & 衣 & 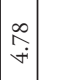 & & $\underset{\mathrm{n}}{\mathrm{N}}$ & in & $\begin{array}{l}\stackrel{\circ}{a} \\
\vec{y}\end{array}$ & $\underset{\exists}{\sharp}$ & $\stackrel{\infty}{\tilde{n}}$ & 荪 & & ફે & 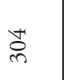 & $\stackrel{\overbrace{}}{-}$ & $\overrightarrow{⿱ 亠 乂}$ & & 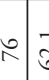 & 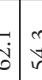 & in & . \\
\hline$\supset$ & 㤩 & & $\begin{array}{l}\text { S. } \\
\stackrel{0}{-}\end{array}$ & 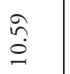 & 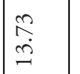 & $\mid \begin{array}{c}\hat{\alpha} \\
\infty\end{array}$ & & ָิ & ثै & $\begin{array}{l}\text { Dे } \\
\text { ले }\end{array}$ & $\begin{array}{l}\infty \\
6\end{array}$ & ๙ু & $\begin{array}{l}\infty \\
\stackrel{+}{*}\end{array}$ & & $\stackrel{\infty}{\triangleright}$ & $\stackrel{\approx}{\sim}$ & $\stackrel{\curvearrowright}{\curvearrowright}$ & $\tilde{\curvearrowright}$ & & $\stackrel{\forall}{=}$ & $\begin{array}{l}0 \\
\vdots \\
\vdots\end{array}$ & 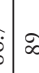 & \\
\hline \multicolumn{2}{|c|}{ 点 } & 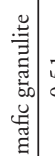 & $\overline{\tilde{o}}$ & tr. & $\stackrel{\sim}{\stackrel{2}{*}}$ & $\stackrel{n}{\rightarrow}$ & 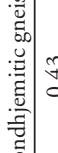 & $\stackrel{\overbrace{}}{\stackrel{?}{0}}$ & $\begin{array}{l}\stackrel{n}{a} \\
\tilde{o}\end{array}$ & $\stackrel{H}{ت}$ & :̊ & ָุ & ָี & 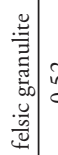 & ֶิ & $\stackrel{\overbrace{}}{0}$ & 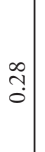 & ్ֶֻ & & $\stackrel{m}{\circ}$ & 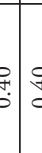 & 8 & \\
\hline 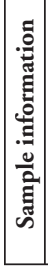 & 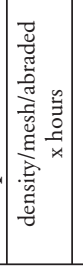 & 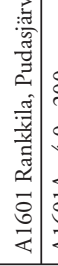 & 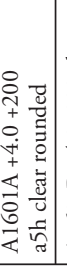 & 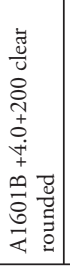 & 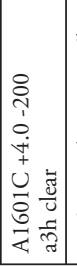 & 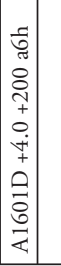 & 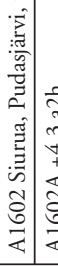 & 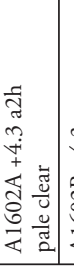 & 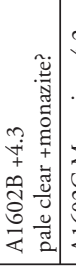 & 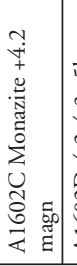 & 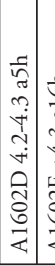 & 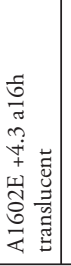 & 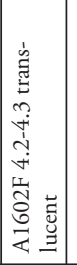 & 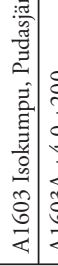 & 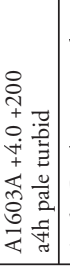 & 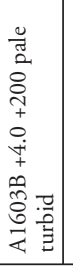 & 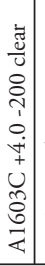 & 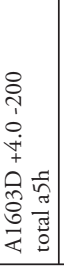 & 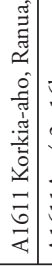 & 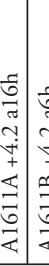 & 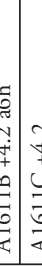 & 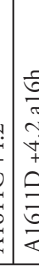 & 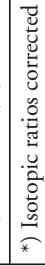 \\
\hline
\end{tabular}




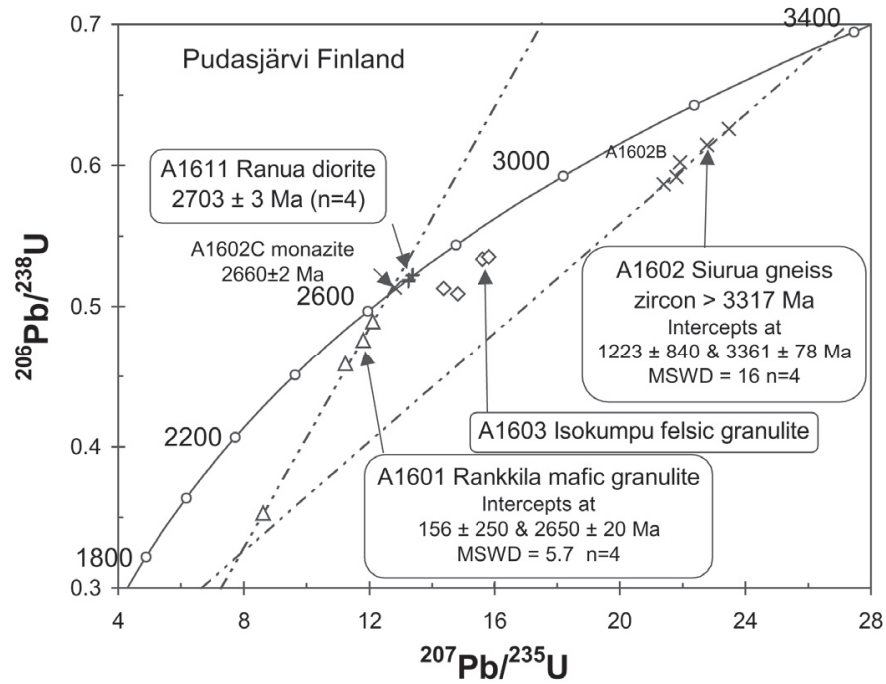

Fig. 6. U-Pb concordia plot of conventional zircon and monazite data for rocks of the Pudasjärvi Granulite Belt and Ranua diorite. the individual analyses are very old, and give a minimum age of $3317 \mathrm{Ma}$ for the zircon.

Ion-microprobe $\mathrm{U}-\mathrm{Th}-\mathrm{Pb}$ analytical data for A1602 zircons are presented in Table 3 and in Fig. 7. Most of the data points appear to be reverse discordant, although there appeared to be no problems with the $\mathrm{Pb} / \mathrm{U}$ calibration performed on 91500 during this session; the reason for this problem remains unclear but may for example be related to localized charging issues around the zircons, or significant compositional differences between these zircons and the 91500 standard. However, repeated analyses to the same spots yield consistent $\mathrm{Pb} / \mathrm{Pb}$ ratios (n1176-01a, -01d and n1176-10a, -10b) and suggest that the ${ }^{207} \mathrm{~Pb} /{ }^{206} \mathrm{~Pb}$ ages are reliable. Fifteen grains of the total 18 analysed yield ${ }^{207} \mathrm{~Pb} /$ ${ }^{206} \mathrm{~Pb}$ ages of 3.4-3.5 Ga. One of these crystals has a distinct core, which gives an age of $3.73 \mathrm{Ga}$ (Fig. 8a). The three youngest ${ }^{207} \mathrm{~Pb} /{ }^{206} \mathrm{~Pb}$ ages are 3.35 Ga, 3.27 Ga and 3.12 Ga. The cathodoluminescence $(\mathrm{CL})$ images reveal that zircons in sample A1602 are CL-dark and internally relatively homogeneous, many grains showing faint prismatic zoning (Fig. 8b). Most crystals have a very thin $(2 \mu \mathrm{m})$ CL-light rim close to the surface. There is no distinct structural control between the different age groups, and the zircon population appears to be relatively homogeneous also in optical microscope. The data do not allow indisputable determination of exact magmatic age for the Siurua gneiss. This is not uncommon for ancient gneisses, which often tend to provide complicated age patterns and problems with interpretation (e.g. Whitehouse et al 1999). Several zircons in sample A1602 are ca. $3.5 \mathrm{Ga}$ old, which is considered as the best estimate for igneous crystallization of the Siurua gneiss. Abundant $3.4 \mathrm{Ga}$ ages may be explained by sub-solidus age-resetting of igneous zircons, metamorphic recrystallisation of igneous zircons or precipitation of new zircon from metamorphic fluids aided by breakdown of $\mathrm{Zr}$ bearing minerals such as hornblende (Mezger and Krogstad, 1997; Fraser et al. 1997). There are four analyses on the crystal n1176-01, from which three give ages of $3.5 \mathrm{Ga}(01 \mathrm{a}$ and $01 \mathrm{~d}$ from the same spot, Fig. $8 \mathrm{~b}$ ), whereas $01 \mathrm{c}$ gives an age of $3.4 \mathrm{Ga}$. The low $\mathrm{Th} / \mathrm{U}$ in analysis $01 \mathrm{c}$ (0.12) suggests metamorphic recrystallisation. However, in CL image the domain is not clearly distinct. As the gneiss is slightly migmatitic, the formation of felsic segregations may be associated with some zircon growth (e.g. $3.12 \mathrm{Ga}$ ). None of the sims ages are close to the $2.66 \mathrm{Ga}$ monazite. However, the conventional data with ${ }^{207} \mathrm{~Pb} /{ }^{206} \mathrm{~Pb}$ ages of $\mathrm{ca}$. 3.3 Ga suggest that the proportion of younger zircon might be larger than expected from the sims analyses. It is possible that the outer rims with thin CL-light bands 


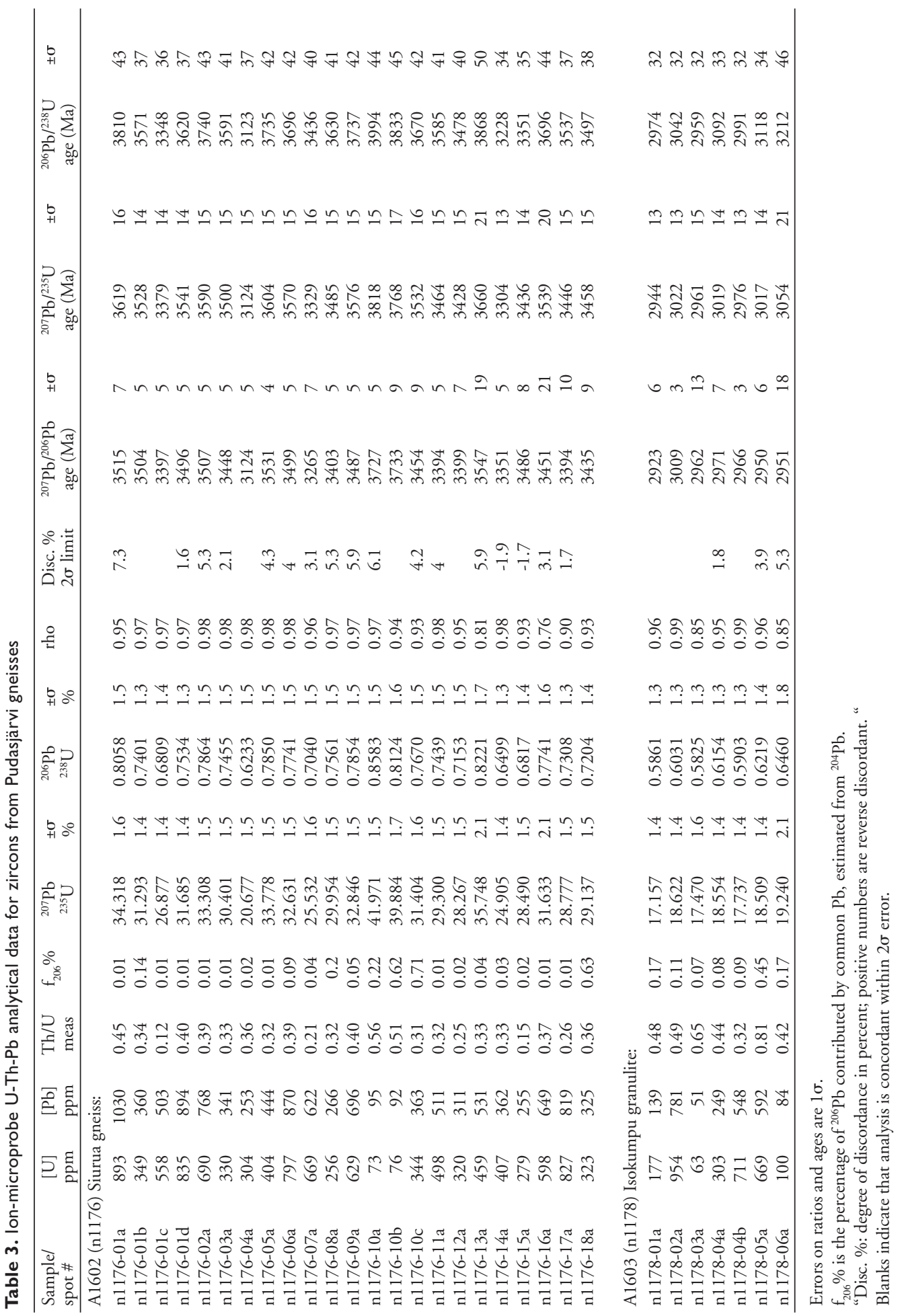




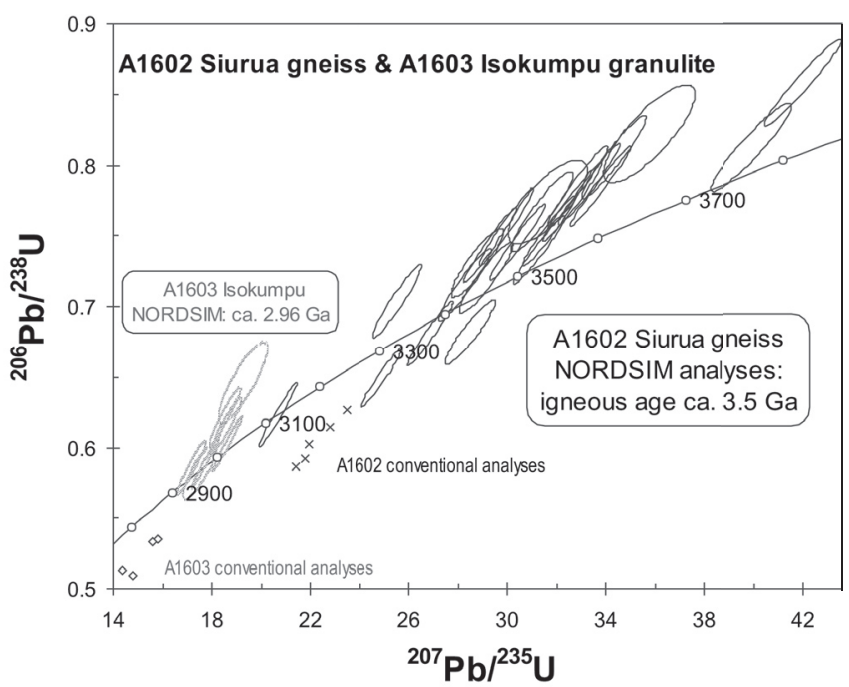

Fig. 7. U-Pb concordia plot of zircon data from Al602 and Al 603. in zircons represent this younger metamorphic effect. This is also supported by the relatively low $\mathrm{Th} / \mathrm{U}$ ratio in conventional bulk analyses (ca. 0.25 calculated from the radiogenic ${ }^{208} \mathrm{~Pb} /$ ${ }^{206} \mathrm{~Pb}$ in table 2) compared to the $\mathrm{Th} / \mathrm{U}$ in sims analyses (table 3 ).

As the zircon population has primarily a magmatic and relatively homogeneous appearance and the rock itself is considered magmatic, it can be concluded that the Siurua trondhjemite gneiss is the oldest rock so far identified in the Fennoscandian Shield. Signs of an even older crustal contribution are obtained from a $3.73 \mathrm{Ga}$ old zircon core.

Sample A1603, Isokumpu, Pudasjärvi, felsic granulite, map sheet 3514 06, coordinates $\mathrm{x}=7279.40, \mathrm{y}=3476.55$.

This rock is relatively homogeneous, granoblastic, medium-grained and massive. The zircon crystals are mostly light-coloured, moderately elongate euhedral prisms that are rounded on edges, probably due to resorption. Many grains, especially in the coarse fraction, are relatively turbid.

The conventional U-Pb data are discordant and heterogeneous. The ${ }^{207} \mathrm{~Pb} /{ }^{206} \mathrm{~Pb}$ ages range from $2.85 \mathrm{Ga}$ to $2.94 \mathrm{Ga}$; the latter is considered a minimum age for the average zircon.

Six zircon crystals from sample A1603 were analysed by ion-microprobe (Table 3, Fig. 7).
Four crystals give ${ }^{207} \mathrm{~Pb} /{ }^{206} \mathrm{~Pb}$ ages of ca. 2.96 $\mathrm{Ga}$, the other two are $2.92 \mathrm{Ga}$ and $3.01 \mathrm{Ga}$. In CL-images the $2.96 \mathrm{Ga}$ crystals show marked regular oscillatory zoning (Fig. 8c). The $3.01 \mathrm{Ga}$ ${ }^{207} \mathrm{~Pb} /{ }^{206} \mathrm{~Pb}$-age was measured from a CL-dark and homogeneous core. The age of the magmatic-looking zircons is ca. $2.96 \mathrm{Ga}$, which is considered the best estimate for the igneous age of the sample A1603. No distinct metamorphic zircon growth was detected in isotopic studies, but thin rims with CL-light band on zircons may well represent younger overgrowths.

Sample A1611, Korkia-aho, Ranua, diorite, map sheet 3524 05, $\mathrm{x}=7322.230, \mathrm{y}=3476.746$.

The dated diorite sample contains less mafic minerals and is finer in grain size than outcropping diorites in general. Abundant zircon crystals separated from the sample A1611 (TM-9933.1) are nearly colourless, clear, subhedral to anhedral and moderately elongate. Many grains show regular oscillatory zoning, which may be interpreted as magmatic.

The four $\mathrm{U}-\mathrm{Pb}$ analyses on zircon are practically concordant and provide an age of $2.703 \pm 0.003 \mathrm{Ga}$, which should represent the crystallization age of the diorite (Fig 6). Consequently, the Ranua diorite is not related to the 2.44 Ga magmatism, as has been occasionally speculated. 

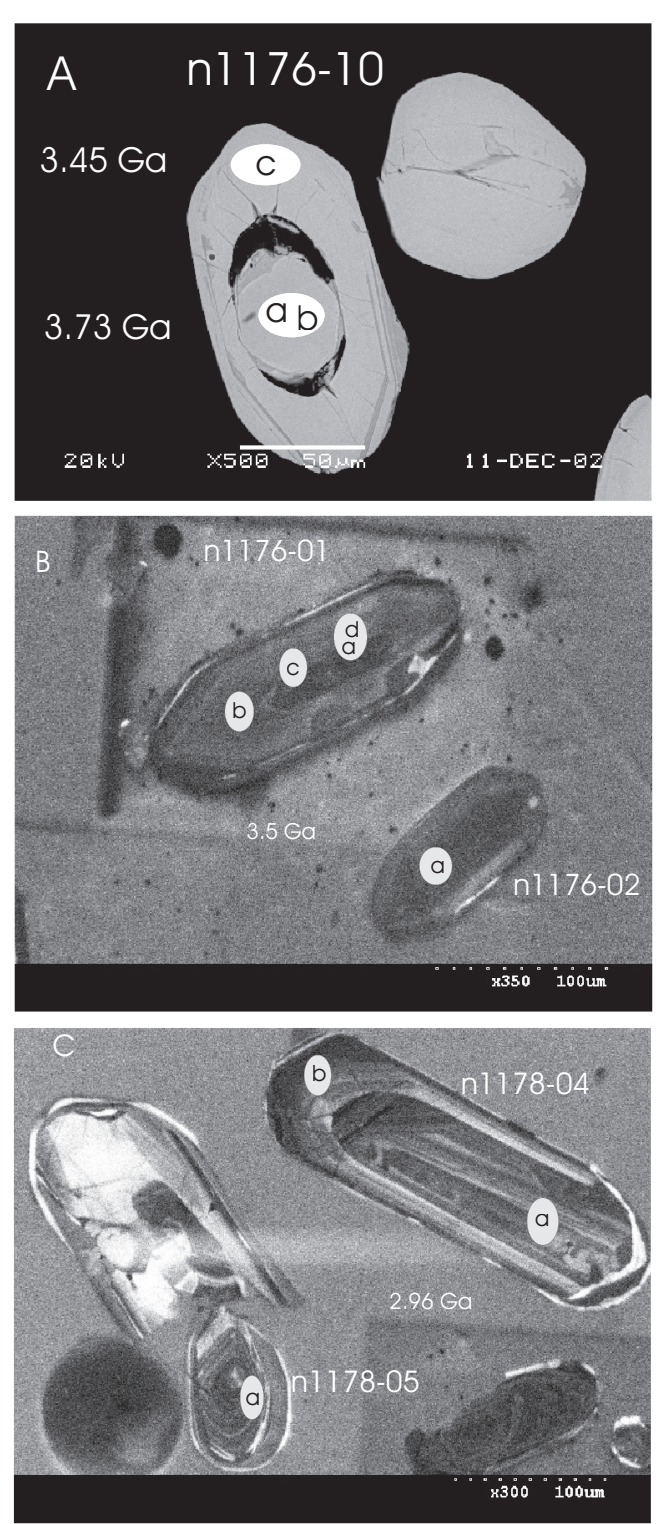

Fig. 8. BSE and CL images of selected zircon grains from, a) Siurua gneiss A I602, grain $\mathrm{n} \mathrm{I} \mathrm{76-10,} \mathrm{b)} \mathrm{grains} \mathrm{n} \mathrm{I} \mathrm{76-}$ $0 \mathrm{I}$ and $\mathrm{nII76-02}$, and c) Isokumpu granulite AI603, grains nI I78-04 and nI I78-05.

\subsection{Sm-Nd whole rocks analyses}

The Sm-Nd analyses on whole rocks give constraints on the crustal residence age, especially when the rocks analysed have typical crustal REE patterns. If metamorphic $\mathrm{Sm} / \mathrm{Nd}$ fractionation has occurred, the results are obviously misleading. The data on five samples analysed in this study are shown in Table 4, which also reports $\varepsilon$ values calculated using an age of $2.7 \mathrm{Ga}$. If $\mathrm{Sm} / \mathrm{Nd}$ fractionation took place during late Archaean, this epsilon value should be more reliable than model ages when comparing different materials.

The composition of the mafic granulite A1601 is typical for many basalts, with only slight LREE enrichment. The calculation of a crustal residence age for such a composition is not warranted, but the initial $\varepsilon \mathrm{Nd}(\mathrm{T})$ of +1.0 (2.7 Ga ago) is common for late Archaean juvenile rocks.

The other rocks in this study exhibit $\mathrm{Sm} /$ $\mathrm{Nd}$ ratios quite normal for felsic crust ( $\mathrm{Ta}$ ble 4). The initial $\varepsilon$ value $(+0.8$ at $2.7 \mathrm{Ga})$ for the Ranua diorite A1611 is similar to the mafic granulite above, and the model age of $2.8 \mathrm{Ga}$ suggests negligible involvement of much older crustal material in its genesis. The Siurua trondhjemite A1602, in contrast, has a $\mathrm{T}_{\mathrm{DM}}$ age of $3.48 \mathrm{Ga}$. It should be noted that the LREE concentration is high in this rock. Due to the low $\mathrm{Sm} / \mathrm{Nd}$ ratio the initial epsilon at $2.7 \mathrm{Ga}$ is very low (-10.8), and thus this analysis can be regarded as a reliable indication of ancient crustal material, strongly supporting the old zircon age for this rock.

The REE concentrations are rather low in the felsic granulite A1603 and alaskite (granite) TM-00-13, yet the LREE patterns $(\mathrm{Sm} / \mathrm{Nd})$ of these rocks are similar. The $\mathrm{Sm}-\mathrm{Nd}$ analysis on A1603 gives an $\varepsilon$ of -3.0 and a model age of 3 $\mathrm{Ga}$. This suggests that the origin of the rock is different from the ancient crust recorded by the Siurua gneiss above. The result from the granite TM-00-13 (with unknown age) indicates a still younger average protolith, as the $\mathrm{T}_{\mathrm{DM}}$ is ca. $2.76 \mathrm{Ga}$. This statement relies on the general assumption that the $\mathrm{Nd}$-isotopic composition in the newly formed granite represents the average protolith. There are indications of isotopic disequilibrium associated with anatexis (Davies \& Tommasini, 2000), and it remains obscure whether granites with low REE concentration are more suspect. It is also conceivable, that some $\mathrm{Sm} / \mathrm{Nd}$ fractionation has occurred during 
Table 4. Sm-Nd data on whole rocks of the Pudasjärvi Granulite Belt and Ranua diorite.

\begin{tabular}{|c|c|c|c|c|c|c|c|}
\hline Sample & Rock type & $\begin{array}{c}\mathrm{Sm} \\
(\mathrm{ppm})\end{array}$ & $\begin{array}{c}\mathrm{Nd} \\
(\mathrm{ppm})\end{array}$ & $\begin{array}{c}{ }^{147} \mathrm{Sm} /{ }^{144} \mathrm{Nd} \\
( \pm 0.4 \%)\end{array}$ & $\begin{array}{c}{ }^{143} \mathrm{Nd} /{ }^{144} \mathrm{Nd} \\
( \pm 0.002 \%)\end{array}$ & $\begin{array}{l}\text { Nd-epsilon } \\
\text { (at } 2.7 \mathrm{Ga} \text { ) }\end{array}$ & $\begin{array}{l}\mathrm{T}_{\mathrm{DM}} \\
(\mathrm{Ma})\end{array}$ \\
\hline A1601 Rankkila & mafic granulite & 2.27 & 8.27 & 0.1660 & 0.512145 & 1.0 & \\
\hline A1602 Siurua & $\begin{array}{l}\text { trondhjemite } \\
\text { gneiss }\end{array}$ & & 78.18 & 0.0807 & 0.510025 & -10.8 & 3481 \\
\hline A1603 Isokumpu & felsic granulite & 0.81 & 6.10 & 0.0799 & 0.510408 & -3.0 & 3009 \\
\hline A1611 Korkia-aho, Ranua & diorite & 6.67 & 35.79 & 0.1126 & 0.511186 & 0.8 & 2808 \\
\hline TM-00-13 & alaskite & 1.04 & 6.41 & 0.0984 & 0.510956 & 1.3 & 2763 \\
\hline
\end{tabular}

${ }^{143} \mathrm{Nd} /{ }^{144} \mathrm{Nd}$ is normalized to ${ }^{146} \mathrm{Nd} /{ }^{144} \mathrm{Nd}=0.7219$. Errors are 2 standard errors of mean.

$\mathrm{T}_{\mathrm{DM}}$ is calculated according to DePaolo (1981).

metamorphism, and the model ages should be taken with some reservation.

\section{Conclusions}

The Archaean Pudasjärvi gneiss complex contains a wide range of rocks with igneous ages from 3.5 Ga in the Siurua gneiss (A1602) to 2.7 Ga in the Ranua diorite (A1611). The Sm$\mathrm{Nd}$ depleted mantle model ages range from 3.5 to $2.8 \mathrm{Ga}$, respectively, and suggest that the Archaean complex consists of rocks with large range of primary crustal formation ages.

The orthopyroxene-bearing high-grade rocks within the complex are considered to form a belt, the Pudasjärvi Granulite Belt, which is, however, poorly delineated at the moment. Metamorphic zircon formed in a mafic granulite (A1601-Rankkila) ca. 2.65 Ga ago, roughly contemporaneously with the $2.66 \mathrm{Ga}$ monazite in the Siurua gneiss. The age is close to the highgrade metamorphism encountered in the Varpaisjärvi granulite area, eastern Finland (Hölttä et al., 2000). The rocks at Varpaisjärvi were metamorphosed at 9-11 kbar (Hölttä \& Paavola, 2000), whereas at Pudasjärvi preliminary pressure estimates are much lower (Lalli, 2002). Magmatic zircons in a felsic granulite (A1603Isokumpu) in the $\mathrm{PGB}$ provide $\mathrm{U}-\mathrm{Pb}$ ages of $\mathrm{ca}$. $2.96 \mathrm{Ga}$, but no zircons coeval with the $2.65 \mathrm{Ga}$ metamorphism were detected. It is conceivable that thin rims on zircons both in felsic granulite (1603) and Siurua gneiss (A1602) were formed during regional metamorphism.
The ion-microprobe zircon $\mathrm{U}-\mathrm{Pb}$ age of 3.5 Ga reveals that the trondhjemite gneiss from Siurua, Pudasjärvi, is the oldest rock so far identified in the Fennoscandian Shield. Signs of an even older crustal contribution are obtained from a 3.73 Ga old zircon core.

\section{Acknowledgements}

We thank Heikki Juopperi, Pekka Tuisku, Katja Lalli, Bo Johanson, Lassi Pakkanen, Eero Hanski, Viena Arvola, Eija Hyvönen, Seppo Aaltonen, Pauli Vuojärvi, Matti Karhunen, Leena Järvinen, Tuula Hokkanen, Lasse Heikkinen, Marita Niemelä, Arto Pulkkinen and Irmeli Mänttäri for help in field, office and laboratory. Chemical analyses are made at the laboratory of the Geological Survey of Finland (GTK). Matti Vaasjoki is acknowledged for comments on early version of the manuscript. Reviews by Stephen Daly and an anonymous referee are acknowledged.

On our wish the technical department of the Pudasjärvi municipality kindly exposed and cleansed large areas of the Siurua gneiss outcrop, for which we thank the municipality director Paavo Pikkuaho, administrative manager Esko Malinen, technical manager Ilpo Koponen and all the other persons who were engaged in the cleansing work.

The NORDSIM facility is operated and funded under an agreement between the research councils of Sweden, Finland, Denmark and Norway and the Swedish Museum of Natural History. Martin Whitehouse, Kerstin Lindén and Lev Ilyinsky are greatly acknowledged. This is a NORDSIM contribution \#87.

Editorial handling: Yrjö Kähkönen and Petri Peltonen 


\section{References}

Alapieti, T., 1982. The Koillismaa layered igneous complex, Finland-its structure, mineralogy and geochemistry, with emphasis on the distribution of chromium. Geological Survey of Finland, Bulletin 319, 116 p.

Bibikova, E.V. \& Williams, I.S., 1990. Ion microprobe $\mathrm{U}-\mathrm{Th}-\mathrm{Pb}$ isotopic studies of zircons from three early Precambrian areas in the U.S.S.R. Precambrian Research 48, 203-221.

Bowring, S.A. \& Williams, I.S., 1999. Priscoan (4.00$4.03 \mathrm{Ga}$ ) orthogneisses from northwestern Canada. Contributions to Mineralogy and Petrology 134, 316.

Carmichael, I.S.E., Turner, F.J., \& Verhoogen, J., 1974. Igneous petrology. McGraw-Hill, New York, 739 p.

Chekulaev, V.P., Lobach-Zhuchenko, L.K. \& Levskii, L.K., 1997. Arkheiskie granity Karelii kak pokazateli sostava i vozrasta kontinentalnoi kory. Geokhimiya $8,805-816$.

Claesson, S., Huhma, H., Kinny, P. \& Williams, I., 1993. Svecofennian detrital zircon ages-implications for the Precambrian evolution of the Baltic Shield. Precambrian Research 64, 109-130.

Davies, G.R. \& Tommasini, S., 2000. Isotopic disequilibrium during rapid crustal anatexis: implications for petrogenetic studies of magmatic processes. Chemical Geology 162, 169-191.

DePaolo, D.J., 1981. Neodymium isotopes in the Colorado Front Range and crust-mantle evolution in the Proterozoic. Nature 291, 684-687.

Enkovaara, A., Härme, M. \& Väyrynen, H., 1952. Oulu-Tornio. General Geological Map of Finland 1:400 000, Pre-Quaternary rocks, Sheet C5-B5, OuluTornio. Geological Survey of Finland.

Enkovaara, A., Härme, M. \& Väyrynen, H., 1953. Kivilajikartan selitys. Explanation to the map of rocks. Map sheet C5-B5, Oulu-Tornio. General Geological Map of Finland 1: 400 000. Geological Survey of Finland, 153 p.

Fraser, G., Ellis, D. \& Eggins, S., 1997. Zirconium abundance in granulite-facies minerals, with implications for zircon geochronology in high-grade rocks. Geology 25, 607-610.

Frost, B.R., 1991. Stability of oxide minerals in metamorphic rocks. In: Lindsley, D.H. (ed.) Oxide minerals: petrologic and magnetic significance, Reviews in Mineralogy 25, 169-187.

Hanski, E., Walker, R.J., Huhma, H. \& Suominen I., 2001. The Os and Nd isotopic systematics of c. 2.44 Ga Akanvaara and Koitelainen mafic layered intrusions in northern Finland. Precambrian Research, 109, 73-102.

Hölttä, P., Huhma, H., Mänttäri, I. \& Paavola, J., 2000. P-T-t development of Archaean granulites in Varpaisjärvi, Central Finland, II: Dating of high-grade metamorphism with the U-Pb and Sm-Nd methods. Lithos 50, 121-136.

Hölttä, P. \& Paavola, J., 2000. P-T-t development of Archaean granulites in Varpaisjärvi, central Finland. I. Effects of multiple metamorphism on the reaction history of mafic rocks. Lithos 50, 97-120.

Huhma, H., Hölttä, P. \& Paavola, J., 1995. Isotopic studies on the Archaean Varpaisjärvi granulites. In: Glebovitsky, V.A. \& Kotov, A.B. (eds.) Precambrian of Europe: stratigraphy, structure, evolution and mineraliza- tion. $9^{\text {th }}$ Meeting of the Association of European Geological Societies (MAEGS), St. Petersburg. Abstracts, Russian Academy of Sciences, 42-43.

Huhma, H., Kontinen, A. \& Laajoki, K., 2000. Age of the metavolcanic-sedimentary unit of the Central Puolanka Group, Kainuu schist belt, Finland. 24. Nordiske Geologiske Vintermöte Trondheim, 6.-9. Januar 2000. Abstracts, Geonytt nr. 1, 87-88.

Hyppönen, V., 1983. Ontojoen, Hiisijärven ja Kuhmon kartta-alueiden kallioperä. Summary: Pre-Quaternary rocks of the Ontojoki, Hiisijärvi and Kuhmo map-sheet areas. Geological Map of Finland 1: 100000 . Explanation to the maps of pre-Quaternary rocks, sheets 4411, 4412 and 4413. Geological Survey of Finland, $60 \mathrm{p}$.

Jahn, B.M., Vidal, B. \& Kröner, A., 1984. Multichronometric ages and origin of Archaean tonalitic gneisses in Finnish Lapland: a case for long crustal residence time. Contributions to Mineralogy and Petrology 86, 398-408.

Kamber, B.S, Moorbath, S. \& Whitehouse, M.J., 2001. The oldest rocks on Earth: time constraints and geological controversies. In: Lewis, C.L.E. \& Knell, S.J. (eds.): The Age of the Earth: from $4004 \mathrm{BC}$ to AD 2002. Geological Society, London, Special Publications, 190, 177-203.

Korsman, K., Koistinen, T., Kohonen, J., Wennerström, M., Ekdahl, E., Honkamo, M., Idman, H. \& Pekkala, Y. (eds.), 1997. Bedrock map of Finland 1:1 000 000. Geological Survey of Finland.

Kröner, A. \& Compston, W., 1990. Archaean tonalitic gneiss of Finnish Lapland revisited: zircon ion microprobe ages. Contributions to Mineralogy and Petrology 104, 348-352.

Kröner, A., Puustinen, K. \& Hickman, M., 1981. Geochronology of an Archean tonalite gneiss dome in northern Finland and its relation with an unusual overlying volcanic conglomerate and komatiitic greenstones. Contributions to Mineralogy and Petrology 76, 33-41.

Krogh, T., 1973. A low-contamination method for hydrothermal decomposition of zircon and extraction of $U$ and $\mathrm{Pb}$ for isotopic age determinations. Geochimica et Cosmochimica Acta 37, 485-494.

Lalli, K., 2002. Pudasjärven granuliittivyöhykkeen Isokummun alueen petrografia, geokemia ja metamorfinen petrologia. Unpublished M.Sc. thesis. University of Oulu, Finland, 105 p.

Lindsley, D.H., 1991. Experimental studies of oxide minerals. In: Lindsley, D.H. (ed.) Oxide minerals: petrologic and magnetic significance, Reviews in Mineralogy 25, 69-106.

Lobach-Zhuchenko, S.B., Sergeev, S.A., Guskova, E.G. \& Krasnova, A.F., 1986. Pervye dannye ob izotopnom vozraste i paleomagnetizme bazitov i ultrabazitov Vodlozerskogo bloka Karelii. Doklady Akademii Nauk SSSR 290, 1184-1187.

Ludwig, K.R., 1991. PbDat 1.21 for MS-DOS: A computer program for processing $\mathrm{Pb}-\mathrm{U}-\mathrm{Th}$ isotope data. Version 1.08. U.S. Geological Survey Open-File Report 88-542, 35p.

Ludwig, K.R., 2001. Users Manual for Isoplot/Ex rev. 2.49. Berkeley Geochronological Center Special Publication No. 1a, 55 p. 
Mänttäri, I. \& Hölttä , P., 2002. U-Pb dating of zircons and monazites from Archean granulites in Varpaisjärvi, Central Finland: Evidence for multiple metamorphism and Neoarchean terrane accretion. Precambrian Research 118, 101-131.

Martin, H., 1994. The Archean gray gneisses and the genesis of continental crust. In: Condie, K.C. (ed.) Archean Crustal Evolution, Developments in Precambrian Geology 11, Elsevier, 205-259.

Mezger, K. \& Krogstad, E.J., 1997. Interpretation of discordant U-Pb ages: an evaluation. Journal of Metamorphic Geology 15, 127-140.

Mints, M.V., Sobotovich, E.V. \& Tson, O.V., 1982. Svintsovo-izokhronnoe datirovanie gornykh porod Murmanskogo bloka i ego obramleniya (Kolskii poluostrov). Izvestiya Akademii Nauk SSSR, Ser. Geol. 10, 5-17.

Mutanen, T., 1989. Koitelainen intrusion and KeivitsaSatovaara complex. $5^{\text {th }}$ International Platinum Symposium. Geological Survey of Finland, Guide 28, 49 p.

Nironen, M., Lahtinen, R. \& Koistinen, T., 2002. Suomen geologiset aluenimet -yhtenäisempään nimikäytäntöön. Subdivision of Finnish bedrock-an attempt to harmonize terminology. Geologi 54, 8-14.

Nutman, A.P., McGregor, V.R., Friend, C.R.L., Bennett, V.C. \& Kinny, P.D., 1996. The Itsaq Gneiss Complex of southern Greenland; the world's most extensive record of early crustal evolution (3900-3600 Ma). Precambrian Research 78, 1-39.

O'Connor, J.T., 1965. A classification for quartz-rich igneous rocks based on feldspar ratios. U.S. Geological Survey, Professional Paper 525-B, 79-84.

Paavola, J., 1986. A communication on the U-Pb and $\mathrm{K}-\mathrm{Ar}$ age relations of the Archaean basement in the Lapinlahti-Varpaisjärvi area, Central Finland. In: Korsman, K. (ed.) Development of deformation, metamorphism and metamorphic blocks in eastern and southern Finland. Geological Survey of Finland, Bulletin 339, 7-15.

Perttunen, V. \& Vaasjoki, M., 2001. U-Pb geochronology of the Peräpohja Schist Belt, northwestern Finland. In: Vaasjoki, M. (ed.) Radiometric age determinations from Finnish Lapland and their bearing on the timing of Precambrian volcano-sedimentary sequences. Geological Survey of Finland, Special Paper 33, 45-84.

Price, G.D., 1981. Subsolidus phase relations in the titanomagnetite solid solution series. Americal Mineralogist 66, 751-758.

Richard, P., Shimizu, N. \& Allègre, C.J., 1976. ${ }^{143} \mathrm{Nd} /$ ${ }^{146} \mathrm{Nd}$, a natural tracer: an application to oceanic basalts. Earth and Planetary Science Letters 31, 269278.
Sergeev, S.A., Bibikova, E.V., Levchenko, O.A., LobachZhuchenko, S.B., Yakovleva, S.Z., Ovchinnikova, G.V., Neimark, L.A., Komarov, A.N. \& Gorokhovskii, B.M., 1990. Izotopnaya geokhronologiya Vodlozerskogo gneisovogo kompleksa. Geokhimiya 1, 73-83.

Shurkin, K.A., Dobrokhotov, M.N., Zagorodnyj, V.G., Negrutsa, V.Z., Sokolov, V.A., Stenar, M.M. \& Shcherbak, N.P., 1979. Vostochno-Evropeiskoi platformy (stratigrafiya, korrelyatsiya). In: Shurkin, K.A. \& Sokolov, V.A. (eds.) Stratigrafiya arkheya i nizhnego proterozoya SSSR. Leningrad, Nauka, 5-23.

Sood. M.K., 1981. Modern igneous petrology. John Wiley \& Sons, New York. 244 p.

Stacey, J.S. \& Kramers, J.D., 1975. Approximation of terrestrial lead isotope evolution by a two-stage model. Earth and Planetary Science Letters 26, 207-221.

Stern, R.A. \& Bleeker, W., 1998. Age of the world's oldest rocks refined using Canada's SHRIMP: The Acasta Gneiss Complex, Northwest Territories, Canada. Geoscience Canada 25, 27-31.

Sun, S.S. \& McDonough, W.F., 1989. Chemical and isotopic systematics of oceanic basalts; implications for mantle composition and processes. In: Saunders, A.D. \& Norry, M.J. (eds.) Geological Society Special Publications 42, 313-345.

Tolppi, T.-P., 1999. Metavulkaniittien geokemia ja hydroterminen muuttuminen Karahkalehdossa Oijärven arkeeisella alueella. Unpublished M.Sc. thesis. University of Oulu, Finland, 80 p.

Wasserburg, G.J., Jacobsen, S.B., DePaolo, D.J., McCulloch, M.T. \& Wen, T., 1981. Precise determination on $\mathrm{Sm} / \mathrm{Nd}$ ratios, $\mathrm{Sm}$ and $\mathrm{Nd}$ isotopic abundances in standard solutions. Geochimica et Cosmochimica Acta $45,2311-2323$.

Whitehouse, M., Claesson, S., Sunde, T. \& Vestin, J., 1997. Ion microprobe U-Pb zircon geochronology and correlation of Archaean gneisses from the Lewisian Complex of Gruinard Bay, northwestern Scotland. Geochimica et Cosmochimica Acta 61, 4429-4438.

Whitehouse, M.J., Kamber, B.S. \& Moorbath, S., 1999. Age significance of U-Th- $\mathrm{Pb}$ zircon data from early Archaean rocks of west Greenland-a reassessment based on combined ion-microprobe and imaging studies. Chemical Geology 160, 201-224.

Wiedenbeck, M., Allé, P., Corfu, F., Griffin, W.L., Meier, M., Oberli, F., von Quadt, A., Roddick, J.C. \& Spiegel, W., 1995. Three natural zircon standards for $\mathrm{U}-\mathrm{Th}-\mathrm{Pb}$, Lu-Hf, trace element and REE analysis. Geostandards Newsletter 19, 1-23. 